\section{Serologic Evidence}

\section{Of L. australis A}

\section{In a Georgia Patient}

L. E. Starr, D.V.M., Ph.D.,

M. M. Galton, Sc.M.,

John Ammons, M.D.,

Charles LeMaistre, M.D., and

R. W. Menges, D.V.M.

$\mathrm{T}$ HE SEROTYPE Leptospira australis A Ballico was first isolated by Cotter and Sawers (1) in 1934 in northern Queensland, Australia. It was reported recently by Derrick and others (2) as the second most common serotype in Australia and accounted for 87 percent of the leptospirosis cases that occurred in canefield workers. The principal animal carrier was found to be a native rat, Rattus conatus (3). In addition, this serotype was isolated from the kidney of a dog in Makasar by Mochtar (4) and from hedgehogs and yellowthroated mice, Apodemus flavicollis, in Czechoslovakia by Kmety (5).

No evidence of $L$. australis A infection was found in the United States until 1955, when two cultures isolated from raccoons in Decatur County, Ga. (6), were identified in the Communicable Disease Center's Leptospira Research Laboratory ( 7$)$. Subsequently, presumptive identification has been made of 3 other isolations from raccoons and 1 from an opossum in southwestern Georgia.

In August 1956 a macroscopic slide aggluti-

Dr. Starr is public health veterinarian, division of epidemiology, Georgia Department of Public Health. Mrs. Galton is chief, and Dr. Menges, a veterinarian, Leptospira Research Laboratory, Epidemiology Branch of the Communicable Disease Center, Public Health Service, Chamblee, Ga. Dr. Ammons is assistant resident at Grady Memorial Hospital, and Dr. LeMaistre is associate professor of medicine, Emory University, both in Atlanta. This paper was presented at the meeting of the Southern Branch of the American Public Health Association on May 8 , 1958, at Little Rock, Ark. nation test antigen was prepared from the first L. australis A strain isolated in southwestern Georgia. The antigen was incorporated into the battery of leptospiral antigens used to screen all human and animal serums examined in the laboratory. Routine use of this antigen led to the detection of $L$. australis $A$ antibodies in serum from a patient in October 1957. The history of the patient's illness and the subsequent epidemiological investigation are described in this report.

\section{Case History}

J. W., a 14-year-old white schoolboy, awoke on October 11, 1957, with generalized malaise. Several hours later he had a headache accompanied by rapid onset of pain in both calves and knees that was aggravated by movement. The muscular pains spread to the thighs, and nausea with vomiting began. Fever was first noted in the evening of the day of onset. The following day, October 12, after 36 hours of clinical illness, he was admitted to Grady Memorial Hospital. On admission, temperature was $104^{\circ} \mathrm{F}$. (rectal) ; pulse, 92 ; blood pressure, $130 / 65$.

When questioned, the patient revealed that he had been swimming in a creek on a farm near Atlanta 10 days prior to admission. During the 2 weeks prior to onset of illness he had stayed with an aunt who owned a dog and several hogs. Many rats had been seen around the aunt's home and hogpens.

On examination, he appeared acutely ill and moderately lethargic. A generalized skin rash was present, most marked over the trunk, extremities, and face, but there was no eruption on either the palms or soles. Each circumscribed, maculopapular eruption measured 0.5 to $1.0 \mathrm{~cm}$. in diameter and blanched on pressure. The pharynx was diffusely injected without exudate. There was no evidence of conjunctivitis, jaundice, joint tenderness, or swelling. Results of electrocardiogram were within normal limits. The initial white blood count was 8,300 per cc. with 76 percent segmented forms, 4 percent band forms, and 20 percent lymphocytes. The sedimentation rate was $41 \mathrm{~mm}$. per hour. Urinalysis revealed a specific gravity of 1.025, 3 red blood cells per high-power field 
with only an occasional white blood cell. No albumin, sugar, or acetone was detected. Cerebrospinal fluid pressure, protein, and sugar content were within normal limits. There were 12 lymphocytes per high-power field.

Blood was obtained on the second full day of hospitalization (October 14) and cultured in Fletcher's medium for leptospires. The patient was then given injections of 600,000 units of procaine penicillin every 4 hours and of $250 \mathrm{mg}$. of chloramphenicol every 6 hours. Fever characterized the first 2 days after admission. Rectal temperature ranged up to $105^{\circ} \mathrm{F}$. on the first day, but did not go above $100^{\circ} \mathrm{F}$. on the second day, and thereafter remained normal. Marked subjective improvement occurred on the morning of the second hospital day. Although the total peripheral white blood count remained within normal limits, progressive lymphocytosis which reached 40 percent was present during the second week of hospitalization. Hepatic function was within normal range, and acute and convalescent serums were negative when tested for agglutination with typhoid, paratyphoid, brucella, and $\mathrm{OX}-19$ antigens.

Skin biopsy of the rash showed a mild perivascular, acute inflammation. Muscle biopsy was unremarkable. The patient was discharged on the 10th hospital day and has remained well.

Serum obtained from the patient the third day after onset of illness was negative when tested by macroscopic slide agglutination with 12 leptospiral antigens, but a second sample collected on the seventh day of illness showed a positive slide test with $L$. australis $\mathbf{A}$ antigen. When tested by microscopic agglutination with a battery of 18 live leptospiral antigens, the second serum sample reacted only with $L$. australis A antigen to a titer of 1:200. For serum samples obtained from the patient on the $10 \mathrm{th}, 12 \mathrm{th}, 25 \mathrm{th}$, and $42 \mathrm{~d}$ days after onset of illness, titers of $1: 1,600,1: 1,600,1: 400$, and 1:400, respectively, were demonstrated against L. australis A antigen. (These titers were confirmed by A. D. Alexander, of the Walter Reed Army Institute of Research.) No reaction was obtained with the remaining 17 leptospiral antigens. Serum obtained from the patient 11 months later (September 1958) reacted to a titer of $1: 100$ with $L$. australis A antigen. No leptospires were isolated from the blood cultured on the third day of illness.

\section{Epidemiological Investigation}

In early November, about a week after the patient was released from the hospital, a visit was made to his home to obtain further information regarding his possible exposure, but no one was at home. About a week later the patient and the aunt with whom he had stayed prior to his illness were found, and arrangements were made to visit the aunt's home and the site where the patient had been swimming. Conditions about the aunt's home were conducive to rat infestation. Although she had used warfarin about 3 weeks earlier, arrangements were made to set traps around the premises. Near the house were several hogpens with eight hogs standing in mud about 6 inches deep. Blood samples were collected from two of the hogs for leptospiral agglutination tests.

The creek where the patient had been swimming, approximately 4 miles from College Park, Ga., ran through a pasture in which cattle were grazing. The swimming "hole" was at the edge of a thickly wooded area. Fox and raccoon tracks were observed on the creek bank. Permission was granted by the owner to obtain blood specimens from the cattle and to set traps for wild animals in the vicinity of the creek. All trapping was done with the assistance and cooperation of the Fulton County Health Department, the U. S. Fish and Wildlife Service, and the Insect and Rodent Control Section of the Communicable Disease Center.

Twelve traps were set in and around the aunt's home and hogpens, but only one young rat (Rattus norvegicus) was caught, probably because of the recent use of warfarin. No leptospires were isolated from the kidney and urine of this rat, and no leptospiral antibodies were detected in the serum. Blood specimens from the two hogs were negative also in 12 leptospiral antigens when tested by slide agglutination.

Serum from 2 of the 4 cattle tested showed a weakly positive slide agglutination reaction to Leptospira pomona antigen. Traps were set in the vicinity of the creek for 3 nights, 15 to 20 traps each night. A total of 3 opossums, 3 
swamp rabbits, and 1 red fox were caught. Leptospira ballum was isolated from the kidney and urine of one opossum and its serum agglutinated with $L$. ballum antigen. No leptospires were obtained from kidney and urine cultures of the other animals, and no leptospiral antibodies were detected. It is interesting that Salmonella give was isolated from the urine of another opossum and Salmonella typhimurium from the kidney of the third opossum.

It was learned that three other boys, ages 14 to 16 years, went swimming with the patient. When questioned, they stated they had not been ill. Serum samples were not obtained from them until approximately $31 / 2$ months after the patient's illness and no leptospiral antibodies were detected.

The aunt's dog had died shortly after the patient's illness. A local veterinarian stated that symptoms exhibited by the dog before death did not indicate leptospirosis.

\section{Comment}

The clinical symptoms exhibited by the patient and the demonstration of a rise and fall in antibody titer to Leptospira australis $\mathbf{A}$ Ballico, together with a history of both direct and indirect exposure to animals, suggest a diagnosis of leptospirosis probably caused by a member of the australis A serogroup or a related serotype.

While the limited epidemiological studies did not reveal evidence of $L$. australis $\mathbf{A}$ infection in animals around the home in which the patient had stayed prior to his illness or in those that had access to the creek, Leptospira ballum was isolated from one of the opossums trapped near the creek. Previous studies in Virginia (8),
Louisiana (9), and Georgia (6) have shown that opossums may harbor at least seven leptospiral serotypes including $L$. australis A. Thus, the most likely hypothesis as to the possible source of the boy's infection appears to be the creek which may have been contaminated by infected opossums or other wild animals.

\section{REFERENCES}

(1) Cotter, T. J. P., and Sawers, W. C.: A laboratory and epidemiological investigation of an outbreak of Weil's disease in northern Queensland. M. J. Australia 2: 597-605, Nov. 10, 1934.

(2) Derrick, E. H., Gordon, D., Ross, C. J., Doherty, R. L., Sinnamon, C. N., MacDonald, V. M., and Kennedy, J. M.: Epidemiological observations on leptospirosis in north Queensland. Australasian Ann. Med. 3: 85-97, May 1954.

(3) Johnson, D. W.: Australian leptospiroses. M. J. Australia 2: 724-731, Nov. 11, 1950.

(4) Van Thiel, P. H. : The leptospiroses. Ed. 1. Leiden, Netherlands, Universitaire Pers Leiden, 1948, p. 186.

(5) Kmety, E. : Leptospirosenherde in der Slowakei. Zentralbl. Bakt. 163: 464-476, October 1955.

(6) McKeever, S., Gorman, G. W., Chapman, J. F., Galton, M. M., and Powers, D. K. : Incidence of leptospirosis in the wild mammals from southwestern Georgia with a report of new hosts for six serotypes of leptospirae, 1957. Am. J. Trop. Med. \& Hyg. 7 : 646-655, November 1958.

(y) Galton, M. M., Powers, D. K., McKeever, S., and Gorman, G. W.: The identification of two leptospiral serotypes new to the United States. Pub. Health Rep. 72 : 431-435, May 1957.

(8) Yager, R. H., Gochenour, W. S., Jr., Alexander, A. D., and Wetmore, P. W. : Natural occurrence of Leptospira ballum in rural mice and in an opossum. Proc. Soc. Exper. Biol. \& Med. 84: 589-590, December 1953.

(9) Roth, E. E., and Knieriem, B. B.: The natural occurrence of $L$. pomona in an opossum ; A preliminary report. J. Am. Vet. M. A. 132 : 97-98, Feb. 1, 1958.

\section{Air Pollution Control Association Meeting}

The annual meeting of the Air Pollution Control Association will be held June 22-26, 1959, at the Hotel Statler, Los Angeles, Calif. The latest equipment for air pollution control will be displayed in the exhibit area, where experts will demonstrate the equipment and answer questions. Copies of papers presented at technical sessions will be incorporated in printed proceedings. 